\title{
The Construction of the Science in the Community website: Antecedents, Foundations, Hybrid Narratives and Epistemological Content
}

\author{
A Construção do Sítio Ciência na Comunidade: \\ Antecedentes, Fundamentos, Narrativas Híbridas e \\ Conteúdo Epistemológico
}

\section{Paulo César Pinheiro ${ }^{\circledR}$ Brazil}

The article presents the antecedents and foundations which led to the construction of the website Science in the Community, a virtual environment just created to share experiences on local cultural knowledge using the internet. Initially, it describes the proposal of folk knowledge insertion into chemistry and science education in Brazil and other related emphases in the international literature, highlighting teachers' education, its problems and a debate involving indigenous knowledge and the nature of science. Next, it describes the results of empirical inquiries in classrooms and the convergence with literature to offer epistemological content for teachers based on hybrid narratives. As a theoretical background, it presents the concepts of hybridization/hybridism, of narrative and the epistemological dimension of the analysis carried out. The methodological procedures emphasize the construction of hybrid utterances and their dialogic, semantic, syntactic and iterative architecture; the development of activities on languages, images, assertions from literature, and the way the epistemological content was analyzed and organized according to five axes/texts: the knowledges and their contexts, languages, practices, theories, and representations. This set of resources is for those who want to deepen their knowledge on local and scientific knowledge relationships, underlining the mixing of languages as a way to communicate both contents, the absence of authoritarian voice on such a construction and the inextricable link between knowledge and context for the task of knowledge's representation and epistemological comparison.

Keywords: local knowledge; hybrid narratives; epistemological content.

$\mathrm{O}$ artigo apresenta os antecedentes e fundamentos que levaram à construção do sítio Ciência na Comunidade, um ambiente criado recentemente na internet para compartilhar experiências de interação com saberes culturais locais. Inicialmente descreve a proposta de inserção de saberes populares na educação em química e ciências no Brasil e ênfases correlacionadas observadas na literatura internacional, destacando a formação docente, seus problemas e um debate envolvendo o conhecimento indígena 
e a natureza da ciência. Em seguida, apresenta resultados de estudos empíricos em salas de aula e a convergência com a literatura para oferecer conteúdo epistemológico para professores com base em narrativas híbridas. Como fundamentos, apresenta os conceitos de hibridização/hibridismo, narrativa e a dimensão da análise epistemológica efetuada. Os procedimentos metodológicos destacam: a construção de enunciados híbridos e sua arquitetura dialógica, semântica, sintática e iterativa; o desenvolvimento de atividades com linguagens, imagens e afirmações da literatura e a direção de analisar e organizar o conteúdo epistemológico em cinco eixos/textos: os saberes e seus contextos, linguagens, práticas, teorias e representações. Esse conjunto de recursos é destinado aos que querem aprofundar seus conhecimentos sobre as relações entre saberes culturais locais e científicos, destacando a mistura de linguagens como forma de comunicar os conteúdos, a ausência de voz autoritária nesta construção e a indissociável relação entre conhecimento e contexto para as tarefas de representação e comparação epistemológica dos saberes.

Palavras-chave: saberes locais; narrativas híbridas; conteúdo epistemológico.

\section{Introduction}

The word community usually evokes feelings of familiarity, comfort and safety. It may have two meanings, referring to a geographical place where people live and know each other or to a group interacting/collaborating/communicating with similar interests and actions, regardless of living in the same place. The verbs belong, participate, and share summarize its meanings, but they are also exclusive as put aside people from other places or who do not have similar interests. In general, communities are plural, internally heterogeneous and may show knowledge, practices and attitudes related to science and school curricula. An important community in this context is the "rational community" of science. The school functions as its extension, since it is where its knowledge and norms are taught, although this may not be always successful and becomes a problem when students do not understand or share the same knowledge and values. A possible pathway is to study science locally or associate it to what exists in their communities or social environments. The website Science in the Community is an environment recently created on the Internet to share such experiences. This article presents the literary and empirical antecedents, as well as the theoretical framework that led to the proposal of an initial set of resources which combines hybrid narratives, activities and epistemological content. The purpose is to support its understanding, and to discuss its contributions, especially the type of dialogized interrelation set forth between the cultures from community and science, as well as the nature of the epistemological analysis carried out. 


\section{National perspectives}

In the analysis of the history of science education in Brazil, Nascimento, Fernandes, and Mendonça (2010) noted the current movements of scientific-technological education and scientific literacy for all and their presuppositions toward wide relationships between science, technology, society and the environment. They also highlighted the insertion of science into culture as a form to understand it by all citizens. The National Curricular Guidelines for Basic Education (Ministério da Educação, 2013) emphasize the approach to Brazilian culture and the link between education and society. Essentially, the guidelines adopt a multicultural curricular perspective as suggest receptivity to the different knowledge and cultural expressions in the country, being understood as a possible way to minimize low school performance. The interaction between folk culture and disciplinary knowledge has been considered in order to value, analyze and understand the former in school. For secondary education, the guidelines point to the dependence of the scientific-technological-cultural dimensions and propose the integration of labor, science, technology and culture in the basis of curricula development.

An important mark for folk knowledge insertion into chemistry education in Brazil was the book A Educação no Ensino de Química (Chassot, 1990), particularly the chapter in which the author seeks to "rescue the chemistry in folk knowledge", settling it as "a relatively new work area in Chemistry Education" (p.103). The subject was retaken later in two chapters of a new book (Chassot, 2001), with similar aims: to "rescue the science in folk knowledge" and to search for "science education out of the classroom". In these three texts, we found presuppositions, foundations, methodological orientation and examples of folk knowledge and practices that can be studied in science education. An assumption is "to work critically the science of the scientist, the school science and folk science", which one with their own features, interactions, "mutual discredits", "resistances and misunderstandings". In his writings, Chassot criticizes the school (and the Academy) for "turning its back to folk knowledge", despising it as "making the court to institutionalized knowledge" (Chassot, 1990, p. 104, 105). On the contrary, he proposes to value and respect folk knowledge, but notes that sometimes it shows contents that are not found in the curricula or there is no correlated scientific knowledge available, requiring research. Undoubtedly, however, this approach demands a different pedagogy:

The proposal that is advocated implies the request to rescue the chemistry that is embedded in the physical and social reality experienced by students (or in other realities) and analyze with them, in a dialogical way, the different meanings and forms of the knowledge construction. (Chassot, 1990, p. 104)

This proposal stated the inception of a perspective that not only sensitized science education researchers and educators in Brazil, but also led to its wide acceptance. In other words, it has not been questioned or contested yet, but, on the contrary, has been reinforced. In the national journal Química Nova na Escola, for instance, there are seven experiences related to the issue referring to Chassot's preliminary ideas. One 
was reported by himself (Chassot, 2008a) and others by Francisco Junior, Yamashita, and Martines (2013); Gondim and Mol (2008), Leal and Moita Neto (2013), Resende, Castro, and Pinheiro (2010), Silva, Aguiar, and Medeiros (2000); Venquiaruto, Dallago, Vanzeto, and Pino (2011). Chassot (2008b, p. 198) has also referred to folk knowledge as "primeval knowledge" or "primeval science", denoting its relationship to early or primeval knowledge. On his work, there is a clear historical connotation.

The Revista Brasileira de Pesquisa em Educação em Ciências (RBPEC) has shown some experiences as well by means of four published articles: Cavaglier and Messeder (2014), Medeiros and Medeiros (2002), Silva (2003), Silveira and Mortimer (2011). The first one exhibited how the theme of medicinal plants might be inserted into the Education of Young and Adults (an educational modality in the country intended for those who lost the opportunity to be schooled in regular time), starting from the students' knowledge proceeded by interdisciplinary teaching modules integrating texts, tables, videos, and experiments. The following two authors analyzed the imagery on lightning of individuals from a rural community and pointed out possibilities to explore the associated school contents. The third investigated the concept of proportion in making grout among building workers, and the last two observed convergences and divergences between indigenous and scientific modes of thinking on chemical transformations.

A general characteristic of the publications found at these two journals is the interaction of researchers with ordinary people or specific cultural groups from communities using diverse theoretical and methodological references in order to apprehend their knowledge, explain them scientifically, identify curricular contents and propose didactic materials. There are few studies focused on teachers' education. A report involving such an experience involved academics of pedagogy and was described by Chassot (2008a), whose basis was the students' interaction with the community parallel to the discussion on the steps of an academic research, that is, the professional development took place in the framework of learning how to carry out a research (see Chassot, 2008b).

In an inquiry of the state of art on folk knowledge in science education research in Brazil, Xavier and Flôr (2015) mentioned the shortage of epistemological approaches, although this is a noteworthy trend observed in the RBPEC's articles. Another gap is the absence of classroom experiments, and a problem is the tendency of some to interpret the phrase "making the primeval knowledge school knowledge" (Chassot, 2008b, p. 197) as a kind of anthropophagy followed by an emesis expressed over school laboratory experiments, which although interesting and creative, generally results in the modification of the original matrix of knowledge through its conversion to school science.

In addition, it must be mentioned the original experiences on Ethnomathematics (D’Ambrosio, 1998) in Brazil, which later spread outwards (Etnomatematica, 2001), as well on Ethnoastronomy (Etnoastronomia, 2006) and Ethnobiology (Baptista, \& El Hani, 2009; Baptista, Vargas-Clavijo, \& Neto, 2014), which has revealed recent educational 
approaches. On Ethnochemistry, Francisco (2004) stated a set of definitions to appoint an area or research program between cultural anthropology and chemistry, which aims to analyze knowledge, practices, techniques and technologies related to the use and transformation of materials by different cultural groups from Mozambique, with methodological and epistemological implications for chemistry education and teachers' professional development. Assuming these and other publications, it is questionable how and to what extent they are being addressed in undergraduate courses in Brazil. Do they have sensitized teaching under this perspective? How do teachers see these proposals and ideas? Are there difficulties to apply them? Which? How is teachers' professional development taking place regarding this approach in Brazil and which is its contribution to science education?

\section{Emphases of the international literature}

It is not usual to find the translation for the Portuguese term "saber popular" as "folk" or "popular knowledge" in international science education journals. It was found only in Pomeroy (1994) and the terminology usually found encompasses expressions such as primordial science and technology, primitive science, native technology, indigenous resources, indigenous knowledge, indigenous science, traditional knowledge, traditional ecological knowledge and local technology. These denominations refer to (a) the existence of science and scientific attitudes among native people (Malinowski, 1948 quoted in Maddock, 1981); (b) the rational perception of reality by specific cultural groups, which is culturally dependent and transmitted orally over generations (Ogawa, 1995), and may be found completely or in the form of traces in the daily lives of its inheritors (George, 1999); (c) the expansionist indigenous cultures (Aztec, Mayan and Mongolian, for example) and the long-lived peoples (Aborigines from Africa, the Americas, Asia, Europe and New Zealand) (Snively, \& Corsiglia, 2001); (d) the knowledge that belongs naturally to a group from a particular community (George, 1992); (e) the "local knowledge that is unique to a specific culture or society which contrasts with the international knowledge system that is generated through the global network of universities and research institutes" (Warren, Slikkerveer, \& Brokensha, 1995, p. xv).

The most frequent expressions observed in international journals are indigenous science, indigenous knowledge and traditional ecological knowledge. Although the latter refers to a scientific discipline, it denotes a knowledge that has no origin in the science official institutions. The expression "local technology" was used by Haden (1973) to refer to the domain of iron technology by elders from the Okebu tribe in Uganda in the context of an early experience with chemistry education, which comprises a rare report of experience carried out in classroom. In addition to these denominations, Antweiler (1998) pointed out others, some features and the individuals associated: endogenous, sustainable, autochthonous, from people or folk, oral, cultural, ethnic, ethnoscience, culturally specific, everyday, science of the concrete, practical, mundane cognition, informal, experiential, experimental, of farmers or peasants, and others. The 
use of one or other form has its own reason: "indigenous knowledge" and "traditional ecological knowledge", for instance, were considered by McKinley (2007) as having a political connotation in the international scenario, which suggests to be the case for "folk knowledge" in Brazil, since its inclusion in the curricula was considered as an education political role (Chassot, 1990).

The resources based on culture and on local (place-based, culture-based science education) are objects of an emerging research area in the United States that focuses on the development of pedagogical knowledge content for science teachers (Chinn, 2012). This area was influenced by the movement known as Progressive Education in that country, which had John Dewey as its precursor for his critique on the gap between science and the life of American school students in the late nineteenth century. Similarly, Adams (2012) defined Community Science as a construct to teach and learn founded in making connections between the knowledge that exists in the community and the science learned in school. This latter brought together international experiences based on a dialectical pedagogy responsive to cultural diversity and to the polysemy of the signification of experiences between school and community, which includes to analyze how people see and use science to make decisions in everyday life and comprehend those knowledge that does not use the same terms and understandings, but that can be used to promote learning. The texts by Adams (2012) and Chinn (2012) show educational and teacher's professional development experiences based on culture and on interactions with local community's knowledge with implications for social transformation and sustainable development. Thus, in general, there is a relatively large number of publications in international journals heading to interactions with other ways of knowing in science education, especially the indigenous knowledge. Research areas are consolidating and present proposals, reports and networks experiences for teachers' education. There are common theoretical references, the approaches tend to be more theoretical and philosophical and, like in Brazil, it is unusual to find reports of classroom experiences.

\section{The fierce debate between universalists and multiculturalists}

The indigenous knowledge was at the core of a debate set out in the Science Education journal as soon as the first papers on multicultural science education appeared, before and after the special issue on the subject in 2001. It was characterized as a "fierce debate" which shook the foundations of science education (Mckinley, \& Stewart, 2012; Van Eijck, \& Roth, 2007), showing at least 20 publications including articles, critiques and counter-responses. Some are cited throughout this text and others may be exemplified in Atwater and Riley (1993), Brown-Acquaye (2001), Hodson (1993), McKinley (2001), Montellano (2001), and Stanley and Brickhouse (2001a; 2001b). In the debate, it is observed two distinct and incompatible epistemologies framed by the opposition between universalists and multiculturalists, which may be summarized as follows:

For the most part, science education has remained immune to the multiculturalist 
critique by appealing to a universalist epistemology: that the culture, gender, race, ethnicity, or sexual orientation of the knower is irrelevant to scientific knowledge. It is the natural world that ultimately judges our account of it, not the reverse (Matthews, 1993). Put another way, the reality of the natural world is indifferent to the personal qualities of inquirers. While it is widely recognized that individual scientists are frequently biased, in the long run, the processes of peer review and scientific methodology are assumed to provide an adequate means for correcting such distorting influences.

(...) The universalist tradition has been challenged by philosophers of science, feminist scholars, and most recently, by multiculturalists. The multiculturalists, for example, have pointed out that non-Western approaches to science are not included in the current science curriculum. The universalist response to this has been to recognize the contribution of other cultures to Western science, but to deny that the knowledge systems of such cultures should be understood as "science". (Stanley, \& Brickhouse, 1994 , p. 388, 389)

The key point was the status of traditional ecological knowledge (TEK), which is not officially recognized as science. The article by Snively and Corsiglia (2001) was a trigger, particularly for their contrary assertion, justifying, thus, the inclusion of this knowledge in the science curricula. Universalists, on the other hand, did not recognize this knowledge as being "scientific" because this adjective is used by them to refer to a knowledge that transcends local contexts and is valid everywhere. In contrast, multiculturalists have insisted on the existence of different forms of science. Thus, in one side were the "universalists", defenders of the universal view of science and its epistemological superiority and, in the other, were the "multiculturalists", critics of this view and its exclusivity/exclusion stance reflected on the curricula. However, multiculturalists are not the only who oppose universalists. Since the 1990s, there is a movement against Western imperialist visions regarding other forms of knowledge, largely influenced by the social studies of science. Multiculturalism, postcolonialism, and postmodernism are among the epistemological perspectives of resistance (Cobern, \& Loving, 2001).

The debate in Science Education involved various subjects, such as the place and role of indigenous knowledge in curricula, whether such knowledge can be considered science or a distinct and equally valid form of knowledge, science and indigenous knowledge epistemologies, universality of science, contributions of indigenous knowledge and others. It highlighted the need to define key terms, such as "science", "Western science", "indigenous science" and "school science". In Brazil, there was no opposition when the "folk knowledge" was referred as "folk science" or "primeval science" (Chassot, 1990, p 104; Chassot, 2008b, p. 198). In the American journal, the positions were antagonistic and the major problem was to attribute the status of science to TEK. Therefore, facing possibilities for including other ways of knowing in the curricula, some authors (Cobern, \& Loving, 2001) defined characteristics to distinguish science in basic education. 
Multicultural science education is known in countries originally colonized by Europeans, whose population coexists with indigenous minorities, as in the United States, Australia, Canada, and New Zealand (Aotearoa). In these countries, indigenous cultures suffered a "culticide" or disintegration by interaction with science and colonial education, which contributed to complete or partial destruction of their knowledge systems. Against it, some perspectives have sought to transpose the Eurocentric, imperialist, racist and ethnocentric tendency of the curricula (Cobern, \& Loving, 2001, p. 53; Van Eijck, \& Roth, 2007, p. 929). In relation to TEK, we underline the position of Cobern and Loving (2001), who preferred to do not consider it as science, but as other ways of knowing, which have their own values and merits. According to them, this does neither diminish the status of this knowledge, nor render unjustifiable its insertion into the curricula. They suggested to value knowledge in its multiple forms and origins, alleging that this may help students to realize that "some of the insights from science can be arrived at by other epistemological pathways" as well as "what science can do that other domains of knowledge cannot do" (Cobern, \& Loving, 2001, p. 63). In that same way, Stanley and Brickhouse (2001a, p. 47) mentioned that the "best" that multicultural education can do is to "introduce students to new ways of thinking about the natural world" and "understand some of the fundamental tenets of Western ways of thinking". What stands out from these positions, from the debate in Science Education and by other authors (Mckinley, \& Stewart, 2012) are the implications of indigenous knowledge for the nature of science.

\section{The teacher's professional development and its problems}

A trend in the field of indigenous science education is to see the science teacher as a cultural agent or "culture broker" (Mckinley, \& Stewart, 2012, p. 546), but the teachers' education has its problems:

Indigenous science education and research occurs at a nexus of complex philosophical, historical, psychological, sociological and political relationships that tend to overwhelm the focus on achievement. Unfortunately, these understandings are not held by most science teachers, education officials, or education academics. It is on the latter group, as Graham Smith (1995) argues, that the primary responsibility lands for initiating the work towards ameliorating this lack, despite its limitations. (Mckinley, \& Stewart, 2012, p. 541)

The experiences in this field come mainly from countries such as Canada, New Zealand, Australia, United States, Africa, and Japan. In some, the official curricula also propose the incorporation of indigenous knowledge into non-indigenous schools, as in New Zealand (Mckinley, \& Stewart, 2012) and Canada (Snively, \& Corsiglia, 2005), for instance. However, an enquiry carried out by McKinley and Stewart (2012) showed that science teachers in New Zealand have approached indigenous knowledge superficially and disconnected from their cultural, historical and sociopolitical contexts in classrooms, taking the form of "caricature". They concluded that this knowledge is "out of place" and 
pointed out some reasons: the predominance of a universalist view of science amongst teachers; the purpose of lessons is to teach science; teachers are educated in this sense and, for this reason, are not the appropriate professionals to approach indigenous knowledge in school. This position is surprising as it opposes to what was advocated by many in the debate set forth in the Science Education journal. On the other hand, it is curious to note the mismatch between teaching and research in a country that, according to the authors, is a world leader in research on indigenous science education. This inquiry, however, draws attention to an important aspect regarding the insertion of other ways of knowing into the curricula: the way the knowledge is represented or the image they acquire when they are (re)presented to students. June George (1992) realized this by mentioning that the reconstitution of native knowledge requires a special responsibility in order to correspond factually to reality, but she did not assigned this task to teachers: "The construction of such database is time consuming and there should be no expectation that science teachers do this for themselves. Science education researchers can play a role here" (p. 107).

However, even if science education researchers assist on this task, the knowledge's representation is always problematic, limited, incomplete, and influenced by who represents them (McKinley, \& Stewart, 2012). Adams (2012, p. 1172) believes that teachers can develop initiatives and create "habits-of-mind" to bring the community's cultures to classroom, but admitted that it is necessary that they acquire knowledge about the students' cultures and languages, on the "working knowledge of cultures" that exists in the community and the contents of science. In the Handbook for Culturally Responsive Science Curriculum published in the state of Alaska/USA, which has been outstanding worldwide for its educational advances in the field, Stephens (2003) predicted the following obstacles: the teachers may not have knowledge available or understanding on cultural knowledge; the cultural specialists (people from community) may not be familiar, feel uncomfortable or hesitate to work in school; the science textbooks do little to help the development of locally relevant activities; there might be no administrative or community support, and time and commitment are required. Vis-a-vis the teachers' difficulties to understand or accept to work in this frame, Chinn (2007) has adopted the use of "decolonizing methodologies" - communication strategies and critical questioning of the dominant perspectives in school, life and society (p. 1252, 1253).

A justification for the insertion of "perspectives and discursive practices marginalized" in science education was given by Slaton and Barton (2012, p. 517) as an attitude of respect. These authors point out that science education has the power to legitimize knowledge and discourse, but in order to give meaning to different perspectives they suggested the deconstruction of the dominant power and authority in classrooms, and to promote hybrid discourses - to create a "third space" for cultural, social and epistemological change, in which competitive discourses and knowledge are brought into conversation and also serve to challenge and reshape traditional forms of literacy. However, what does the word "deconstruction" mean in this perspective? 
It seems that it means to displace the dominant knowledge and authority from their hierarchically dominant position, without denying, but keeping them erased in some moments according to a play of undoing/preserving positions.

\section{Empirical background}

What originally motivated the investigation on local community knowledge and practices was the distance between science education and its cultural environment (Pinheiro et al., 1985). Thus, I started studies as an undergraduate academic in chemistry and extended them in the graduation and in the supervision of students in projects of scientific initiation, university extension and master thesis. One of the aims was always to elucidate the community's knowledge by scientific explanations. In this sense, research was carried out on technical and scientific books and in laboratories, and for the interactions with the community the first theoretical reference was the participant research (Brandão, 1982; 1987).

At one moment, the classroom experiences went from face to face (direct) interactions between students and the community to the use of mediational means in the form of texts, videos and hypermedia systems. This happened due to difficulties for schedule and space adjustments, and because some individuals in the community did not feel comfortable to work directly with students. The problem then became the knowledge's transportation to classrooms using these means, which Silva (2003, p. 80) called by "transference between contexts" and considered as one of the "great educational problems to be faced by researchers and educators". The option adopted was to follow the recommendations from ethnography of knowledge and practices (D'Olne Campos, 2002), ethnobiology (Posey, 1986), cultural anthropological ethnographies (Clifford, 1998; Geertz 1973; Grills 1998; Malinowski, 1984), and their derivations in the form of photo-ethnographies (Accutti, 2006; Lévi-Straus, 1994) and ethnographic films (France, 2000). The discourse analysis had become an important tool also for identifying the contexts associated to the community's practices in order to incorporate them into ethnographic descriptions - the "web of relations" (Foucault, 1986). The perception of community and science social languages containing specific speech genres (Bakhtin, 1986), in turn, set the basis for comprehending semantical relationships and to promote "cultural border crossings" according to Aikenhead's (1996) pedagogical proposal.

At the present, the experiences joined a set of five traditions related to the making of specific cultural artifacts: the ash soap, the orange wine, the milk candy, the sour cassava, and the craft making of bricks (Pinheiro, Felício, \& Monteiro, 1987; Pinheiro, \& Felício, 1988; Pinheiro, \& Giordan, 2008; Pinheiro, \& Giordan, 2010; Pinheiro, \& Gomes, 2000; Resende, Castro, \& Pinheiro, 2010). Regarding school experiences, what stood out was the students' high level of interest and engagement. When pupils were involved in direct interactions with the community, they initially observed the practices at their development sites and then explored the science contents at the fundamental level of education, making experiments and activities in dialogical classes. The high 
school experiences were those mediated by texts, videos and hypermedia systems. In most cases, the teachers helped to plan the activities and gave way their classes for our activities management. As the production of digital media (video-DVDs and hypermedia) have been emphasized recently, these have been given to teachers in order to know whether and how they would teach with them. In a first experience, a teacher analyzed the hypermedia on the ash soap making and considered to insert it on her chemistry classes, but also said that she would need time to study the contents and prepare the lessons. At this media, the ash soap making knowledge is described and problematized by questions for the students' interpretation. As this activity did not require the teacher's participation, we agreed to begin the work by students' autonomous exploration of the hypermedia organized in groups. Before that, however, it was evident that the teacher required assistance for the pedagogical work, which was made in the form of conversations, suggestions, indication of texts for reading and by offering a second hypermedia as support (Pinheiro, 2007).

After the activities, the teacher revealed her greatest difficulty: how to deal with different views and languages in the classroom. As the students concluded the hypermedia and questions exploration, she carried out experiments, explored the chemistry contents and the second media, in which the students' answers were arranged into electronic pages according to each question formulated. She remarked that the lessons involved three languages: from the community, from science and the pedagogical, whose basis, according to her, was to make connections. She dedicated most of her classes for the exploitation of contents (questions/answers) and attempted to characterize the nature of the knowledge occasionally. She called the one portrayed in the hypermedia as "folk knowledge" and associated it with an "empirical knowledge" which was achieved by "trial and error", missing the "scientific rigor" and had "no further explanations". On her classes, she recognized that these features were not a problem as the knowledge had succeeded "over time". Regarding the "chemistry view", she mentioned it has "a whole explanation" and "an elaborated, organized and systematized knowledge". This "view" was associated to what is taught at school and although the community's knowledge had another route, it showed coherence with the scientific knowledge. As a chemistry teacher, she defended the relevance of this science as a source of reliable explanations, but considered the "two views" as valid. However, she was surprised by the students easy appropriation (in the sense given by Wertsch, 1993) of the community's knowledge and language to build their answers to the questions proposed in the hypermedia, and became troubled with the fact that most responses were not based on school chemistry. Thus, she questioned the students' answers and asked where they would place their "own" knowledge since those classes.

At first sight, there was no problem on the teacher's approach, considering that it was her first experience of this kind. To provide support in the form of contents knowledge was important because it saved time, gave safe and streamlined the pedagogical planning, but it also left a gap: the epistemological content knowledge. For that reason, the teacher 
expressed personal opinions, and her analysis was superficial and brief compared to that of knowledge contents. After this experience, the new hypermedia elaborated began to bring the knowledge from community and science, although separately in different menus. The idea is to promote students' interactions with the community's knowledge first and then answer to questions proposed by means of group's discussions and research, with the possibility to access and select the scientific information available in the media. In this context, the following strategies were adopted in order to give autonomy for teachers in classroom inquiries: 1) to give access to contents through "hybrid narratives", and 2) to carry out an epistemological analysis, and make it available through texts easy to read and understand. To materialize the former, first it was necessary to understand the concept of hybridism.

\section{Hybridism/hybridization}

Hybridism presents several concepts. An overview refers to the combination of two generically distinct parts to produce other with new characteristics and applications. In the 1900s, the word "hybrid" was an important scientific term in biology, but since the 1800s, it was part of a controversial debate on the origins of humanity. At that time, some attributed the offspring sterility of animal crossings to the union of different species and whether this was valid for "races" interbreeding, it could serve as evidence for human polygenism. Many people feared such crosses and the words "miscegenation" and "amalgamation" were used to designate fertile crosses, while "hybrid" referred to infertile succession. This phenomenon began to be studied in plants during the eighteenth century by Joseph Kölreuter and Charles Darwin devoted a chapter in The Origin of Species to hybridism, emphasizing that infertility was not a rule for interspecies crossings and could occur within a same variety, but this was understood only later by the genetics development. Thus, the organic paradigm of the nineteenth century developed parallel to that of hybridism, pressing for the joint growth (or not) of incompatible entities. Several theories have been proposed throughout history showing hybridism both attractive in the sense of mixing and transformation, as repugnant - in the sense of corruption, impurification, degradation and degeneration of human beings. Historically, however, the relations involving language and sex were central to the emergence of the so-called "hybrid" forms (Young, 1995).

This idea also migrated to other areas of science, as in the proposition of the theory of atomic orbitals hybridization to explain the geometry of simple molecules, by the chemist Linus Pauling in 1931. It has also been used in technology: hybrid vehicles are a promise for fuel economy and other hybrid forms are known (hybrid power supplies, hybrid generators, hybrid computers, etc.). Hybridism began to be used in human sciences, particularly in literary theory and criticism, cultural studies, communication studies (especially in Latin America), and anthropology (Lund, 2006, p. xi), with empirical, methodological and critical approaches. Empirically, it denotes a general condition of "mixedeness" or a process of mixture (Stam, 2000 quoted in Lund, 
2006, p.xii). Its methodological invocation signals studies that are attentive to the "inbetween" spaces of cultural production and practice: those who think about what happens to culture as it moves and problematize purist notions. Critically, the hybridism is seen as a "deconstructive lever" or a way to reverse and displace authoritative rhetoric and discourses. More than a mixture of disparate elements, it is used to describe or influence movements in which traditionally considered "low" cultural and social practices come to infiltrate and impinge upon the "high" (Lund, 2006, p. xii). It is at this level that it becomes explicitly oppositional, a kind of subversion that has become a key concept or relevant construct in postcolonial theory (Carter, 2004, p. 826).

In literary works, hybridism appears as a characteristic of novels. Many current novelists and from the past have written "obsessively" on mixture and crossing of identities, whether in terms of class, gender, culture, race, or language. The novels have always emphasized forms of contact, cross-cultural interactions, and the active and frequently sexual desire for the other or the state of being which Hanif Kureishi originally called "an inbetween" (Young, 1985, p. 3). On his analysis of the novel, Mikhail Bakhtin (1981) called hybridization the strategic device used to create an image that is "inextricably woven" with the dialogized interrelationship between languages to compose a "unitary artistic fabric". "What is a hybridization? It is a mixture of two social languages within the limits of a single utterance, between two different linguistic consciousnesses, separated from one another by an epoch, by social differentiation or by some other factor" (Bahktin, 1981, p. 358).

The place of the hybrid construction in the novel is the utterance, or rather, two utterances mixed by a single speaker with "two speech manners", "two styles", "two languages", "two systems of semantic and axiological beliefs" in the limits of a single phrase. Its "syntactic structure utterly specific" also plays an important role. The languages "can never completely exist" in this way, but felt in the "syntactic construction of the double-voiced hybrid". In deliberate hybridization, one language acts as the "image" or "illumination" of another linguistic consciousness, "with each belonging to a different system of language". The fundamental aspect of this type of hybridization is its intentionality, but there is also an unconscious form - the organic hybridization, which is present in the life and historical evolution of all languages: "language and languages change historically primarily by means of hybridization, by means of a mixing of various 'languages' co-existing (...)" (Bakhtin, 1981, p. 358, 359).

Bakhtin's hybridization had an influence on Homi Bhabha's cultural and historical postcolonial hybridism, but was transformed by the latter into an active movement of challenge and resistance against a dominant cultural power (Young, 1995, p. 23). Originally, this movement was described in the analysis of cultural writings from the time of British colonialism, particularly associated to the insertion of the "English Book" - the printed Bible, in colonial India, Africa, and Caribbean (Bhabha, 1998a). The Bible was introduced into the colonies and was translated to some local dialects aiming to modify the religious beliefs of the population. The natives reacted by recognizing its 
value and meanings, but also modified them by removing the word of God from the English medium as a movement of resistance or subversion against colonial authority. As a sign of difference, the "English Book" produced a "repetition", where the colonial authority was acknowledged, but also a "displacement", as a form of resistance (Bhabha, 1998a, p. 161). This "double inscription" made the "English Book" no longer a full presence, nor a representation of an essence, but a "partial presence", "less than one and double": a hybrid ( p. 169).

In what appeared to be the fusion of Bhabha's hybridism with Bakhtin's hybridization, Robert Young proposed a model for cultural interactions:

Bakhtin's doubled form of hybridity therefore offers a particularly significant dialectical model for cultural interaction: an organic hybrid, which will tend towards fusion, in conflict with intentional hybridity, which enables a contestatory activity, a politicized setting of cultural differences against each other dialogically. (Young, 1995, p. 22)

In this model, there is a theoretical and political duplicity insofar as it works in two directions: to merge and create a new form and to disperse, intervene, translate and transform. In the first, hybridism is a junction ("forcing together") that transforms difference into sameness. It implies to make two different things just one, but with the possible reversal to their respective origins. It may also consist in severing ("disrupting") a singular entity in two or more parts (second direction), in order to divide a singular object in two, transforming what is similar into difference, although the parts can be joined again. Hybridism thus moves in two directions, "but in a way that makes the same no longer the same, the different no longer simply different" (Young, 1995, p. 26).

In Bakhtin's approach, the hybridization applied to the construction of "hybrid narratives" pointed to an operation of mixing the social languages of community and science and to the foundation of a semantic internally dialogical relationship according to a specific syntactic arrangement. Bhabha's hybridism, on the other hand, is more complex and has a political connotation as it represents a challenge and resistance to cultural domination by displacing, distorting, and reverting strategically this process through a double vision. When intentionally focused on writing, it implies the creation of a translation space that, at the same time, affirms and contests the original identities, aiming at the construction of a new object or identity.

\section{The hybrid narratives initially written for the Science in the Community website}

A narrative is a literary construction owning some particular elements. Norris, Guilbert, Smith, Hakimelahi, and Phillips (2005) distinguished the following: events, narrator, narrative appetite, time, structure, agency, proposal and reader. In short:

Within the theoretical perspective, one statement in particular has been repeatedly referenced in literary discussions on narrative, and can serve to frame our discussion:

"We might conceive of narrative discourse most minimally and most generally as verbal 
acts consisting of someone telling someone that something happened" (Herrnstein Smith, 1981, p. 228). In this statement are found references to a narrator (someone telling), a narratee (someone receiving, whom, because we are concerned primarily with written stories, we shall call the "reader"), events (something that happened), and past time. We shall consider each of these narrative elements, and also describe important narrative features highlighted by other theorists: narrative appetite, structure, agency, and purpose. (Norris et al., 2005, p. 538)

The narrative appetite is the stimulated desire to know what will happen. Typically, narratives have principle, middle and finale, there is a time relative to the sequence of events, the time of discourse, and a connection between events. These aspects comprise its structure. Agency refers to the characters or actors involved; it is where the human being emerge. To communicate knowledge, feelings, values, beliefs and to help to understand what is happening summarize the proposal.

The works regarding the ash soap and the orange wine making were chosen in order to elaborate the first hybrid narratives for the Science in the Community website. The former involved an inquiry that began in 1984 and continued posteriorly. It involved interactions with eight individuals from four distinct communities and three classroom experiences. The narrative was titled "The women from Minas Gerais and the ash soap", with reference to the predominant gender of the personages and the Brazilian state where they live. The latter theme was studied within an extension project that was carried out in 2002, which consisted by a cycle of interactions with a family and the mediated insertion of the knowledge into a chemistry classroom. It refers to the narrative "Mr. Zé, Mrs. Ná, and the orange wine", as the actors are known by the community. The first narrative is composed of five texts with photographs and links to short videos. The second contains four texts and photographs. Both may be accessed on the following electronic address: http://www.ufsj.edu.br/ciencianacomunidade.

In methodological terms, the narratives were written in a non-hybrid version initially, describing only the community's knowledge and practices. The scientific information was associated next. The first texts of the two narratives introduce a brief history of the researches carried out. The second ones present historical data on the ash soap and orange wine and their relationships with similar artifacts produced in other parts of the world. The following texts describe the actions or procedures and is where the hybridization is effectively realized. To illustrate, two examples of hybrid utterances are presented below, each one belonging to one of the two narratives:

- The ashes are compacted into the "barrilero" using a socket or even the hands: "to be very well pounded". Otherwise, if not well compacted, if not "stick it well into the can", make it "very well pounded", if "put the ash there only and put the water" the "dicuada doesn't get out no": it "gets out weeeak", it becomes diluted, low concentrated. In Aparecida's words this is "to give strongness to the dicuada", to increase the concentration of the ash lye. This is so because "the stronger", the highest concentration of dicuada, "faster makes the soap", quicker will be the saponification reaction rate. 
- He [Mr. Zé] said that "it boils inside the demijohn to turn wine. It releases a gas that bubbles like when water boils to make coffee". The fermentation produces also the carbon dioxide (carbonic gas, $\mathrm{CO}_{2}$ ) and "when it's cold it boils slower". At lower temperature, the fermentative activity decreases producing lesser amount of gas.

\section{The activities proposed}

In the original project of the Science in the Community website there was the idea to propose activities to explore the hybrid narratives, such as exposing hybrid utterances on the computer screen, in which teachers could separate phrases and words by dragging and placing them in spaces using the mouse, according to their provenances: in one side the language of the community and in the other the language of science. This idea was stimulated by Robert Young's (1995) dynamic view of hybridism and was concretized by means of eight activities: two involve the dragging of words and phrases from hybrid texts to specific locations; in the other two it is proposed the semantic association of utterances from the two contexts, and the construction and dismemberment of hybrid texts can be carried out in four activities. In fact, there are 11 activities made for the website: the ninth refers to a game involving images of materials used in the community practices and in scientific laboratories, and the activities 10 and 11 involve assertions regarding school science and the nature of the knowledges, respectively. Mostly, the statements were extracted from the literature and are intended to provoke reflections on teachers and to know their opinions about them: if they agree, disagree, to what extent they agree or disagree, or whether they do not know. This is accomplished by scoring one of five alternatives in questionnaires or giving the answers in specific fields and submitting the responses online. There are 46 assertions in the activity 10 and 49 in the 11. This type of questionnaire was observed in surveys whose items were submitted to peer review; the references are indicated in the Science in the Community website in the flap Theoretical Foundations. Some items are by my own, such as: - To include the community's knowledge in the classes the teachers need to know the scientific knowledge correlated (extracted from Adams, 2012 and from Pomeroy, 1994); - To deal with different ways of knowing in classes it is essential that science teachers have knowledge about the nature of science (extracted from the debate in the journal Science Education).

\section{The epistemological analysis organized in five texts}

The epistemological analysis of the knowledge portrayed by the hybrid narratives was organized in five axes/texts: the knowledge and its contexts, languages, practices, theories and representations. This combination constitutes the epistemological content knowledge primarily proposed for the Science in the Community website, which may be accessed on the flap Nature of Knowledge. For its construction, some articles from the debate of the journal Science Education were first revisited, mainly those that emphasized philosophical aspects and the nature of science. These issues were also analyzed in other literary sources. On local knowledge, texts by anthropologists were used. These 
references are cited in the texts available at the website. One problem was the choice of an epistemological framework that would allow a comparative analysis that would not impair or subjugate the community's knowledge in relation to science, as observed in the Science Education journal debate. The Van Eijck and Roth (2007) analysis suggested an epistemology that can be considered fair by avoiding the epistemological problems of both sides of the debate between universalists and multiculturalists. The first problem concerns the relation between knowledge and reality. In order to evaluate the validity of the knowledge, the two reference frames started from this relationship, but with different constituents. Among the universalists there is the realistic notion that the validity of knowledge is inherent to the plausibility of the relationship between knowledge and material reality. The scientific knowledge satisfies this requirement because it constructs its concepts on this reality. On the other hand, underlying multiculturalism, there is a relativistic notion that the validity of knowledge is inherent to the plausibility of the relation between knowledge and cultural reality. Thus, in the latter, the indigenous traditional ecological knowledge is as valid as the scientific knowledge. Thereby, the knowledges are seen according to different epistemologies, which makes impossible to reduce one to each other; they are "incommensurable", as Van Eijck and Roth (2007, p. 931) noted. To resolve the impasse, these authors suggested binding the physical and cultural realities simultaneously in the analysis.

The second problem concerns the use of the notion of "truth" as a measure for the validation of knowledge, whose concept is problematic insofar as it depends on a given "regime of truth" (Foucault, 1979 quoted in Van Eijck, \& Roth, 2007, p. 931) - the way of thought imposed by associations, institutions or societies of discourse, which determine what is true or false. Rather than establishing this relationship, the authors suggested adopting the "usefulness of knowledge" as an epistemic dimension, considering that knowledge acquires its purpose in specific contexts. In other words, knowledge and context are mutually constitutive. The third problem pointed is the static, singular and homogeneous view of the debaters on knowledge and culture (Van Eijck, \& Roth, 2007), which does not consider the exchanges, relations and the dynamism of the subjects and their cultures:

This notion precisely grabs the cultural identity of peoples, indigenous peoples included, as a dynamic, current entity which actually provides identity by its continuous being (ego existo) as opposed to an entity rooted in a static and never-changing (never-existing) pure foundation from an unknown (unlived) past (res cogitans). (Van Eijck, \& Roth, 2007, p. 932)

These authors used the epistemology of cultural-historical activity theory to carry out an analysis on indigenous and scientific knowledge, continuing the debate in the journal Science Education. In this theory, the knowledge is always knowledge in context and stems from actions where human needs are central: "there is no such thing as knowledge that makes sense independent of human activity" (Henry, 2003 quoted in Van Eijck, \& Roth, 2007, p. 933). Thus, to start, the knowledges depicted in the hybrid 
narratives were associated to their original cultures, social milieus and usefulness: the knowledge on the ash soap and orange wine were associated to the production of these materials for specific purposes while the scientific knowledge to the phenomena explanation. To enhance this particular analysis, the reader may consult the text The knowledge and its contexts in the flap "Nature of Knowledge" on the Science in the Community website.

Although Van Eijck and Roth (2007) employed a fair reference to carry out their epistemological analysis, they also emphasized a common trend in the debate published in the journal Science Education: the foundation of an "ontology of difference" (p. 933). This approach is problematic in the current study because it reinforces the binary oppositions between the knowledges and is averse to postcolonial hybridism, where frontiers are no longer so clear or became "blurred" (Carter, 2004; Mckinley, 2007). In my perception, the difference tends to separate the knowledge while the similarity approaches them, what suggested me to also settle an "ontology of similarity". In the text The knowledge and its practices, for instance, it is mentioned that the activities carried out in the community and in scientific laboratories have the following similarities: they extract substances, separate residues, dissolve materials, collect gases, develop quality tests, observe and control natural phenomena and there is creativity in both ways. Another feature of the epistemological analysis carried out is the joint treatment of the knowledge. It alternates between its contexts, languages, practices and systems of explanation, deepening peculiarities and what is exclusive to one or other. In the analysis, the justification of philosophers of science (Ladrière, 1977; Loving, 1995; Wolpert, 1994) to consider the community's knowledge as "technologies" rather than "science" is highlighted, mainly because of their different motivations and the theorizing process that is unique to the latter. To deepen this aspect, see the text The knowledge and its theories.

\section{Final remarks}

The purpose of this paper was to describe the antecedents, fundamentals and the construction of an initial set of resources available on the Science in the Community website, an environment created on the internet to share experiences of interaction with local cultural knowledge. The starting point was the review of literature on the insertion of other ways of knowing in science education and its convergence with outcomes from classroom experiences in the direction to offer knowledge of epistemological content for teachers. In order to accomplish this task, hybrid narratives, activities and texts on the nature of knowledge of community and science were elaborated and transferred to internet. In order to verify their effects, two questionnaires were prepared for data collection using the website, which will be described in future publications together with the results observed in a first group of participants.

The hybrid narratives produced in our study contain utterances that mix the social languages of the community and science to constitute a dialogized semantic 
interrelationship. On this construction, Bakhtin (1981, p. 359) mentioned that one language acts as the "image" or "illumination" of the other (in our case, the language of science). However, as noted by Faraco (2009), I believe those languages are mutually supportive or interilluminate each other as they configure different ways of knowing set in a dialogical relationship. In the perspective of Bhabha's (1998b) hybridism, each position is always a process of translation and transference of meanings, in which each object displaces itself in relation to the other and is displaced in this act. The activities involving the association and separation of words and phrases exemplify these characteristics, but what is best highlighted in this construction is that in the hybrid text the authority faces a crisis because it is not possible to exist an authoritarian voice on it. It cannot exist as such because of its singularity and inability for being double-voiced (Young, 1995).

The utterances of the hybrid narratives own a syntactic construction, which presents different possibilities: sometimes bringing the community's language and then that of science, sometimes reversing this order and sometimes alternating them dynamically (to realize this, the reader must observe the varied ordination in the hybrid utterances of the narratives in the Science in the Community website). This was achieved by means of a "puzzle", where the words and phrases of each context were positioned and repositioned in different places of the utterances until finding the better forms (or fittings) for each case. Another feature is the iterativity or repetition of hybrid statements throughout the narratives. This was not due exclusively the unfolding of the events/ phenomena, but to the aim of inciting reflection. Bhabha (1998a) mentioned that the reflexive thinking emerges in the cultural interstices according to an incessant process of repetition between going beyond (referring to hybridism) and coming back to the condition of separation/exclusion in order to transform it.

In research contexts, a synonym that has been given to hybridism is "third space" to appoint the "merging or integration of knowledges and discourses" (Moje, Ciechanowski, Kramer, Ellis, Carrillo, \& Collazzo, 2004, p. 41), and to name an "expanded activity" capable of setting "rich zones of collaboration and learning", or "zones of proximal development" with "transformative potential" (Gutierrés, Baquedano-López, \& Tejeda, 1999, p. 286, 287). In the "third space", apparently distinct, opposite or discontinuous categories work together to generate new knowledge, discourses, identities, and forms of literacy. In science education, some studies have used hybridism as a reference for investigating identities of teachers and students and as a framework for indigenous knowledge curricular interactions (McKinley, \& Gan, 2014). To date, I am not aware of other experiences involving the construction and use of hybrid texts in science education. The mixture of languages is not a common characteristic of the literacy in this discipline or in teachers' education. The revised literature did not demonstrate such experience either and a tendency is to observe static, homogeneous, and singular views of other ways of knowing, as observed by Van Eijck and Roth (2007) in the debate between universalists and multiculturalists in the journal Science Education. It must be remembered, however, the intentional aspect of this construction allied to the expectation that teachers realize 
the possibility to create "third spaces" in the interactions with other ways of knowing in science education. Although the contributions for learning and teacher's education are not clear, it is possible to state that this form of literacy gives simultaneous access to both knowledges, whose acquisition by teachers was recommended by Adams (2012) and George (1992). However, that would not have been possible without our (the researcher) support, as the teachers usually do not have knowledge or understanding on cultural knowledge, do not have time to do this by themselves, and the science textbooks do not help (Stephens, 2003).

Bakhtin mentioned that hybridization in the novel consists of an "artistically profound play with social languages" which "demands enormous effort" (Bakhtin, 1981, p. 366, 367), and it is true that this may be acknowledged for the hybridization work carried out here. However, the ethnographic research and the discourse analysis must also be recognized as relevant tools for the narratives construction, whose density is difficult to observe in the literature (see, for instance, the descriptions of indigenous knowledge on salmon run in Cobern, \& Loving, 2001, and in Van Eijck, \& Roth, 2007). In this sense, the internet support was significant for the representation of knowledge in a proper way, although this process is always partial and incomplete.

The epistemological analysis carried out in this study pursued to connect the physical and cultural reality, to identify the knowledges' usefulness and to associate them with their contexts, setting an ontology of similarities and differences more coherent with postcolonial hybridism. The bond with their contexts of development was present in the hybrid narratives and in the epistemological analysis and led to reflect whether this is an essential condition for the adequate treatment of other ways of knowing in science classes, then the same can be said for the scientific knowledge taught in school. This was considered as an attitude of respect by the authors below:

If, for example, the way we teach science in schools leaves silent the sociocultural features that surround the "making of a scientific fact," then how students learn to value each other as users and producers of science is also made silent. (Slaton, \& Barton, 2012, p. 524)

In the current study, the epistemological analysis of the knowledges and practices of both the community and science was organized and made available in five texts on the Science in the Community website. The nature of science analysis carried out differs from that normally observed in publications of the area, which tend to describe authentic contexts of scientific activity, that is, what is emphasized is the "Big Science" (Abd-El-Khalic, 2012). However, literature has shown that teachers have difficulties to adopt epistemological approaches in their classroom, and some specialists have been trying to solve this problem with long-term professional development (Lederman, \& Lederman, 2012). The epistemological analysis reported in this paper differs because it is relational and expresses epistemological content on the community's knowledge. The texts were submitted to appreciation by two experts and were considered to approach the nature of science. They can be read on the Internet and in PDF format, in Portuguese 
and English versions, and are intended for those interested in deepening or acquiring epistemological content on local/cultural and scientific knowledges and to support future investigations regarding teacher's education and classroom experiences.

\section{Acknowledgment}

This study was carried out in a Post-Doctoral internship abroad with the support of the Brazilian agency Coordenação de Aperfeiçoamento de Pessoal de Nível Superior (CAPES - Process BEX № 1992/14-7). I am very grateful to its support and staff, as well as to the personnel from the George C. Mallinson Institute for Science Education/ Western Michigan University/USA, for the great welcoming and help. Special thanks to Dr. William W. Cobern (Director of MISE/WMU), for his remarkable stimulus and assistance, and to Dr. Norman G. Lederman, from the College of Science/Illinois Institute of Technology/USA, for his prompt attention and criticism. I also thank Rosaria Justi, editor of this journal, for her remarkable suggestions and revision of the manuscript.

\section{References}

Abd El-Khalic, F. (2012). Nature of science in science education: toward a coherent framework for synergistic research and development. In B. J. Fraser, K. T. Tobin, \& C. J. McRobbie (Eds.), Second International Handbook of Science Education (pp. 1041-1060). New York, NY: Springer.

Achutti, L. E. R. (2003). Fotos e palavras, do campo aos livros. Revista Studium, 12. Retrieved from http://www.studium.iar.unicamp.br/12/1.html.

Adams, J. D. (2012). Community Science: capitalizing on local ways of enacting science in science education. In B. J. Fraser, K. T. Tobin, \& C. J. McRobbie (Eds.), Second International Handbook of Science Education (pp. 1163-1177). New York, NY: Springer.

Aikenhead, G. (1996). Science Education: border crossing into the subculture of science. Studies in Science Education, 27, 1-52.

Antweiler, C. (1998). Local knowledge and local knowing: an anthropological analysis of contested "cultural products" in the context of development. Anthropos, 93, 469-494.

Atwater, M. M., \& Riley, J. P. (1993). Multicultural science education: perspectives, definitions, and research agenda. Science Education, 77(6), 661-668.

Baptista, G. C. S., \& El-Hani, C. N. (2009). The contribution of ethnobiology to the construction of a dialogue between ways of knowing: A case study in a Brazilian public high school. Science \& Education, 18, 503-520.

Baptista, G. C. S., Vargas-Clavijo, M., \& Neto, E. M. C. (Eds.). (2014). A etnobiologia na educação ibero-americana: compreensão holística e pluricultural da biologia. Feira de Santana/Bahia: UEFS Editora. 
Bakhtin, M. M. (1981). The dialogic imagination: four essays. Austin: University of Texas Press.

Bakhtin, M. M. (1986). Speech genres and other late essays. Austin: University of Texas Press.

Bakhtin, M. (2004). Marxismo e filosofia da linguagem (11th. ed). São Paulo: Hucitec.

Bhabha, H. K. (1998a). O local da cultura. Belo Horizonte: Editora da UFMG.

Bhabha, H. (1998b). The commitment to theory. New Formations, 5, 5-23.

Brandão, C. R. (Org.). (1982). Pesquisa participante (2nd. ed). São Paulo: Brasiliense.

Brandão, C. R. (Org.). (1987). Repensando a pesquisa participante (3rd. ed). São Paulo: Brasiliense.

Brown-Acquaye, H. A. (2001). Each is necessary and none is redundant: the need for science in developing countries. Science Education, 85(1), 68-70.

Carter, L. (2004). Thinking differently about cultural diversity: using postcolonial theory to (re)read science education. Science Education, 88(6), 819-836.

Cavaglier, M. C. S., \& Messeder, J. C. (2014). Plantas medicinais no ensino de química e biologia: propostas interdisciplinares na educação de jovens e adultos. Revista Brasileira de Pesquisa em Educação em Ciências, 14(1), 55-71.

Chassot, A. I. (1990). A Educação no Ensino da Química. Ijuí: Unijuí, 1990.

Chassot, A. I. (2001). Alfabetização Científica: questões e desafios para a educação. Ijuí: Unijuí.

Chassot, A. I. (2008a). Fazendo educação em ciências em um curso de pedagogia com inclusão de saberes populares no currículo. Química Nova na Escola, 27, 9-12.

Chassot, A. I. (2008b). Sete Escritos Sobre Educação e Ciência. São Paulo: Cortez.

Chinn, P. W. U. (2007). Decolonizing methodologies and indigenous knowledge: the role of culture, place and personal experience in professional development. Journal of Research in Science Teaching, 44(9), 1247-1268.

Chinn, P. W. U. (2012). Developing teachers' place-based and culture-based pedagogical content knowledge and agency. In B. J. Fraser, K. G. Tobin, \& C. J. McRobbie (Eds.), Second International Handbook of Science Education (pp. 323-334). New York, NY: Springer.

Clifford, J. (1998). A Experiência Etnográfica: antropologia e literatura no século XX. Rio de Janeiro: Editora UFRJ.

Cobern, W. W., \& Loving, C. C. (2001). Defining "Science" in a multicultural world: implications for science education. Science Education, 85(1), 50-67. 
Corsiglia, J, \& Snively, G. (2001). Rejoinder: Infusing Indigenous Science into Western Modern Science for a sustainable future. Science Education, 85(1), 82-86.

D’Ambrosio, U. (1998). Etnomatemática. 5. ed. São Paulo, SP/Brazil: Ática.

D’Olne Campos, M. (2002). Etnociência ou etnografia de saberes, técnicas e práticas? In M. C. D. Amoroso, L. C. Ming, \& S. P. Silva (Orgs.), Métodos de coleta e análise de dados em etnobiologia, etnoecologia e disciplinas correlatas (pp. 47-91). Rio Claro, SP: Coordenadoria da área de Ciências Biológicas-Gabinete do Reitor-UNESP/CNPq.

Faraco, C. A. (2009). Linguagens e diálogos: as ideias linguísticas do Círculo de Bakhtin. São Paulo, SP/Brazil: Parábola Editorial.

Foucault, M. (1986). A Arqueologia do Saber. (2a. ed). Rio de Janeiro, RJ: Forense Universitária.

France, C. (2000). Antropologia fílmica: uma gênese difícil, mas promissora. In: France, C. (Org.). Do filme etnográfico à Antropologia fílmica. Campinas, SP: Editora da Unicamp. Francisco, Z. L. (2004). O Ensino de Química em Moçambique e os saberes culturais locais (Tese de doutorado). Pontifícia Universidade Católica, São Paulo.

Francisco Junior, W. E. J., Yamashita, M., \& Martines, E. A. L. M. (2013). Saberes regionais amazônicos: do garimpo de ouro no Rio Madeira $(\mathrm{RO})$ às possibilidades de Inter-relação em aulas de Química/Ciências. Química Nova na Escola, 35(4), 228-236.

Geertz, C. (1973). The interpretation of cultures. New York: Basic Books.

George, J. (1988). The role of native technology in science education in developing countries: a Caribbean perspective. School Science Review, 69(249), 815-821.

George, J. (1992). Science teachers as innovators using indigenous resources. International Journal of Science Education, 14(1), 95-109.

George, J. (1999). World view analysis of knowledge in a rural village: implications for science education. Science Education, 83(1), 77-95.

Gondim, M. S. C., \& Mol, G. S. (2008). Saberes populares e ensino de ciências: possibilidades para um trabalho interdisciplinar. Química Nova na Escola, São Paulo, 30, 3-9.

Grills, S. (1998). Doing ethnographic research: fieldwork settings. Thousand Oaks: SAGE Publications.

Gutierrés, K. D, Baquedano-López, P., \& Tejeda, C. (1999). Rethinking diversity: hybridity and hybrid language practices in the third space. Mind, Culture, and Activity, 6(4), 286-303.

Haden, J. (1973). Iron and education in Uganda. Education in Chemistry, 10(2), 49-51.

Hodson, D. (1993). In search of a rationale for multicultural science education. Science Education, 77(6), 685-711. 
Ladrière, J. (1977). The challenge presented to cultures by science and technology. Paris: UNESCO.

Leal, R. C., \& Moita Neto, J. M. (2013). Amido: Entre a Ciência e a Cultura. Química Nova na Escola, São Paulo, 35(2), 75-78.

Lederman, N. G., \& Lederman, J. S. (2012). Nature of scientific knowledge and scientific inquiry: building instructional capacity through professional development. In $\mathrm{B}$. J. Fraser, K. G. Tobin, \& C. J. McRobbie (Eds.), Second International Handbook of Science Education (pp. 335-359). New York, NY: Springer.

Lévi-Straus, C. (1994). Saudades do Brasil. São Paulo, SP/Brazil: Companhia das Letras. Loving, C. C. (1995). Comment on "Multiculturalism, Universalism, and Science Education”. Science Education, 79(3), 341-348.

Lund, J. (2006). The impure imagination: toward a critical hibridity on Latin America writing. Minneapolis, MN/Unites States: University of Minnesota Press.

Maddock, M. N. (1981). Science Education: An Anthropological Viewpoint. Studies in Science Education, 8(1), 1-26.

Malinowski, B. (1984). Os Argonautas do Pacífico Ocidental: um relato do empreendimento e da aventura dos nativos nos arquipélagos da Nova Guiné Melanésia. São Paulo: Abril Cultural.

Mckinley, E. (2001). Cultural diversity: masking power with innocence. Science Education, 85(1), 74-76.

Mckinley, E. (2007). Postcolonialism, indigenous students, and science education. In S. K. Abell, \& N. G. Lederman. (Eds.), Handbook of research on science education (pp. 199-226). Mahwah, NJ: Lawrence Erlbaum.

Mckinley, E., \& Gan, M. J. S. (2014). Culturally responsive science education for indigenous and ethnic minority students. In N. G. Lederman, \& S. K. Abell (Eds.), Handbook of Research on Science Education, Volume II (pp. 284-300). New York, NY: Routledge.

Mckinley, E., \& Stewart, G. (2012). Out of place: indigenous knowledge in the science curriculum. In B. J. Fraser, K. T. Tobin, \& C. J. McRobbie (Eds.) Second International Handbook of Science Education (pp. 541-554). New York, NY: Springer.

Medeiros, A., \& Medeiros, C. (2002). Os raios no imaginário popular. Revista Brasileira de Pesquisa em Educação em Ciências, 2(3), 84-96.

Ministério da Educação. (2013). Diretrizes Curriculares Nacionais para a Educação Básica. Retrieved from http://portal.mec.gov.br/index.php?option=com_ docman\&view=download\&alias=15548-d-c-n-educacao-basica-novapdf\&Itemid=30192 
Moje, E. B, Ciechanowski, K. M, Kramer, K., Ellis, L., Carrillo, R., \& Collazzo, T. (2004). Working toward third space in content area literacy: an exam of everyday funds of knowledge and discourse. Reading Research Quarterly, 39(1), 38-70.

Montellano, B. R. O. (2001). Multicultural science: who benefits? Science Education, 85(1), 77-79.

Nascimento, F., Fernandes, H. L., \& Mendonça, V. M. (2010). O Ensino de Ciências no Brasil: História, Formação de Professores e Desafios Atuais. Revista HISTEDBR On-line, 10(39), 225-249.

Norris, S. P., Guilbert, S. M., Smith, M. L., Hakimelahi, S., \& Phillips, L. M. A. (2005). Theoretical Framework for Narrative Explanation in Science. Science Education, 89(4), 535-563.

Ogawa, M. (1995). Science education in a multiscience perspective. Science Education, 79(5), 583-593.

Pinheiro, P. C., Mendes, L. A., Maurício, L. A., Monteiro, M. B. A., Monteiro, R. A., \& Colli, G. (1985). O fabrico do sabão de cinzas e suas implicações para o ensino de ciências no nível elementar. In Resumos do $1^{\circ}$ Congresso De Educação Através da Química (p. 4-5). Niterói, RJ/Brasil: Universidade Federal Fluminense/Sociedade Brasileira de Química.

Pinheiro, P. C., Felício, E. C., \& Monteiro, R. (1987). The science teaching and the popular technologies: popular technologies of making soap - the ash soap. In Abstracts da Ninth International Conference on Chemical Education (p. 339). São Paulo, SP/Brasil: Universidade de São Paulo/IUPAC.

Pinheiro, P. C., \& Felício, E. C. A. (1988). Sobre uma atividade com o sabão de cinzas na escola de $1^{\circ}$ grau. In Resumos da 40a Reunião Anual da Sociedade Brasileira para o Progresso da Ciência (p. 594). São Paulo, SP/Brasil: SBPC.

Pinheiro, P. C., \& Gomes, A. S. (2000). A produção artesanal de tijolos: um saber patrimonial estudado nas aulas de ciências de uma sala multisseriada. In Resumos da 23a Reunião Anual da Sociedade Brasileira de Química (p. ED005). Poços de Caldas, MG/Brasil: SBQ.

Pinheiro, P. C. (2007). A interação de uma sala de aula de química de nível médio com o hipermídia etnográfico sobre o sabão de cinzas vista através de uma abordagem sócio(trans) cultural de pesquisa (Tese de doutorado). Faculdade de Educação, Universidade de São Paulo, São Paulo.

Pinheiro, P. C., \& Giordan, M. (2008). The interaction between a Brazilian chemistry classroom and the ash soap makers' cultural knowledge mediated by an ethnographic hypermedia narrative. In Abstracts do Second International Society for Cultural and Activity Research Congress. San Diego, Cf/United States: UCSD/ISCAR. 
Pinheiro, P. C., \& Giordan, M. (2010). O preparo do sabão de cinzas em Minas Gerais, Brasil: do status de etnociência à sua mediação para a sala de aula utilizando um sistema hipermídia etnográfico. Investigações em Ensino de Ciências, 15(2), 355-383.

Pomeroy, D. (1994). Science education and cultural diversity: mapping the field. Studies in Science Education, 24(1), 49-73.

Posey, D. (1986). Etnobiologia: teoria e prática. In: Ribeiro, D. (Org.). Suma Etnológica Brasileira (pp. 15-25). Petrópolis: Vozes/FINEP.

Resende, D. R., Castro, R. A., \& Pinheiro, P. C. (2010). O saber popular nas aulas de química: relato de experiência envolvendo a produção do vinho de laranja e sua interpretação no ensino médio. Química Nova na Escola, 32(3), 151-160.

Etnomatemática. (2001). Scientific American Brasil, 11, São Paulo: Duetto.

Etnoastronomia. (2006). Scientific American Brasil, 14. São Paulo: Duetto.

Silva, J. R. S. (2003). O conceito de proporção no contexto da construção civil a partir da mistura argamassa do tipo: cimento x areia. Revista Brasileira de Pesquisa em Educação em Ciências, 3(1), 58-69.

Silva, P. B., Aguiar, L. H., \& Medeiros, C. F. (2000). O papel do professor na produção de medicamentos fitoterápicos. Química Nova na Escola, 11, 19-23.

Silveira, K. P., \& Mortimer, E. F. (2011). Tradição Maxacali e conhecimento científico: diferentes perspectivas para o conceito de transformação. Revista Brasileira de Pesquisa em Educação em Ciências, 11(3), 9-33.

Slaton, A., \& Barton, A. C. (2012). Respect and science learning. In B. J. Fraser, K. T. Tobin, \& C. J. McRobbie (Eds.), Second International Handbook of Science Education (pp. 513-525). New York, NY: Springer.

Snively, G., \& Corsiglia, J. (2001). Discovering indigenous Science: Implications for Science Education. Science Education, 85(1), 6-34.

Snively, G, \& Corsiglia, J. (2005). Response to Carter's postmodern, postcolonial analysis of Snively and Corsiglia's (2000) article "Discovering Science". Science Education, 89(6), 907-912.

Stanley, W. B., \& Brickhouse, N. W. (1994). Multiculturalism, universalism and science education. Science Education, 78(4), 387-398.

Stanley, W. B., \& Brickhouse, N. W. (2001a). Teaching sciences: the multicultural question revisited. Science Education, 85(1), 35-49.

Stanley, W. B., \& Brickhouse, N. W. (2001b). Response to our critics. Science Education, 85(1), 87-88.

Stephens, S. (2003). Handbook for Culturally Responsive Science Curriculum. Fairbanks: Alaska Native Knowledge Network. 
Van Eijck, M., \& Roth, W-M. (2007). Keeping the local local: recalibrating the status of science and traditional ecological knowledge (TEK) in education. Science Education, 91(6), 926-947.

Venquiaruto, L. D., Dallago, R. M., Vanzeto, J., \& Pino, J. C. D. (2011). Saberes populares fazendo-se saberes escolares: um estudo envolvendo a produção artesanal do pão. Química Nova na Escola, 33(3), 135-141.

Warren, D. M., Slikkerveer, L. J., \& Brokensha, D. (Eds.). (1995). The Cultural Dimension of Development: indigenous knowledge systems. London: Intermediate Technology Publications.

Wertsch, J. V. (1993). Voices of the Mind: a sociocultural approach to mediated action (4th ed.). Cambridge: Harvard University Press.

Wolpert, L. (1994). The unnatural nature of science. Cambridge: Harvard University Press.

Xavier, P. M. A., \& Flôr, C. C. C. (2015). Saberes populares e educação científica: um olhar a partir da literatura na área de ensino de ciências. Ensaio, 17(2), 308-328.

Young, R. J. C. (1995). Colonial desire: hybridity in theory, culture and race. London: Routledge.

Paulo César Pinheiro

http://orcid.org/0000-0002-7752-3614 Universidade Federal de São João Del Rei Departamento de Ciências Naturais São João Del Rei, Brazil pcpin@ufsj.edu.br 